\title{
Autobiografia (não) autorizada: eu lírico e autoria em poemas de Mia Couto
}

\author{
Everton Fernando Micheletti \\ Universidade de São Paulo (USP), São Paulo, São Paulo, Brasil \\ efmicheletti@gmail.com \\ http://orcid.org/0000-0003-1526-3332
}

\section{DOI: http://dx.doi.org/10.21165/el.v47i3.1990}

\section{Resumo}

Este artigo visa a analisar alguns poemas do escritor moçambicano Mia Couto, com ênfase na relação entre o eu lírico e o autor empírico, de modo a verificar as co-incidências autobiográficas. Em alguns poemas, o eu lírico se apresenta coincidente com o autor real, como nos textos dedicados ao pai e à esposa. Em outros, há pontos em comum, mas que não são assumidos, deixando aberturas à interpretação. Desse modo, o que se busca não é determinar os sentidos dos poemas e delimitar a interpretação pela via autobiográfica simplesmente, mas verificar como funcionam as várias instâncias da voz nos poemas e, a partir daí, levantar algumas características da produção poética de Mia Couto.

Palavras-chave: Mia Couto; literatura moçambicana; poesia; autoria; eu lírico.

\section{(Un) authorized autobiography: lyrical self and authorship in poems by Mia Couto}

\begin{abstract}
This paper aims to analyze some poems of the Mozambican writer Mia Couto, with focus on the relation between the lyrical self and empirical author, in order to verify the autobiographical coincidences. In some poems, the lyrical self appears coincident with the real author, as in the texts dedicated to his father and to his wife. In others, there are points in common, but they are not assumed, leaving openings to interpretation. In this way, what is sought is not to determine the meanings of the poems and to delimit the interpretation by the autobiographical way simply, but to verify how the various instances of the voice work in the poems and, from there, to raise some characteristics of the poetic production of Mia Couto.
\end{abstract}

Keywords: Mia Couto; Mozambican literature; poetry; authorship; lyrical self.

\section{Introdução}

Mia Couto, escritor reconhecido por sua ampla produção em prosa, também escreve poemas, voltando a se dedicar aos versos após um longo período. ${ }^{1}$ Nos poemas, são recorrentes alguns motivos e temas de seus contos e romances, como as constantes referências e metáforas de árvores, céu, terra, mar, rio, casa, entre outras. A essa espacialidade, ao mesmo tempo local, moçambicana, e universal, em que predominam os elementos de natureza, somam-se a temática da infância, da morte, do relacionamento amoroso e do próprio fazer poético.

\footnotetext{
${ }^{1}$ Seu primeiro livro publicado foi de poemas, Raiz de orvalho, em 1983, revisado e relançado em 1999. O segundo livro de poemas, Tradutor de chuvas, foi publicado em 2011; o terceiro, Vagas e lumes, em 2014.
} 
A diferença que se pode notar nos versos, em comparação com as obras em prosa, é a voz enunciadora, a tendência ao tom lírico, havendo um número considerável de poemas em primeira pessoa, o que permite estabelecer relações entre o autor textual (voz interna no texto, "ficcional") e o autor empírico (externo, o escritor "real"). No modo lírico, como afirma Aguiar e Silva (1984, p. 583, grifos do autor), "o eu do autor textual mantém em geral uma relação de implicação com o eu do autor empírico mais relevante do que no modo narrativo e no modo dramático".

Há, desse modo, poemas em que essas relações são declaradas, com referências à realidade do escritor e, em outros casos, as referências são menos diretas, mas, mesmo assim, podem ter algum tipo de implicação entre o eu lírico e o autor. Como, em ambos os casos, permanecem aberturas à interpretação, entende-se que os aspectos autobiográficos, nos poemas analisados, estão no limite entre serem ou não autorizados, isto é, entre serem ou não indicados e, portanto, "permitidos" pelo autor. No conjunto dos textos, destarte, podem-se encontrar as vozes em suas várias assunções identitárias, os vários "eus". ${ }^{2}$

É importante considerar, é claro, as diversas discussões de correntes teóricas e críticas quanto à autoria e autonomia do texto, as quais, entre meados do século XIX e primeira metade do século XX, vão de um extremo a outro: da defesa do "gênio" do autor e do "biografismo" à recusa da intencionalidade pelo New Criticism e Formalismo Russo, além da "morte do autor" no Estruturalismo. Posteriormente, surgem outras formas de abordagem do texto literário, como a Estética da Recepção, voltada ao papel do leitor. Em décadas recentes, com a intensificação das discussões sobre minorias e os oprimidos socialmente, questiona-se o cânone e reivindica-se espaço para as vozes até então excluídas, retomando-se o valor dos aspectos biográficos, mas não como um determinante único dos sentidos do texto. Além disso, a própria produção literária vem problematizando esse aspecto no caso da chamada "autoficção" que, em termos bastante gerais, como o nome indica, reúne autobiografia e ficção.

Em face disso, vale ressaltar que não se visa a delimitar a interpretação dos poemas pela via autobiográfica pura e simplesmente, mas de verificar como funcionam as relações entre as várias instâncias da voz nos textos, as "co-incidências" - dupla incidência da voz - entre o eu lírico e o autor "real". ${ }^{3}$ A partir do questionamento da cisão

\footnotetext{
2 Em vez de chamar de "eu lírico" a voz enunciadora no poema, alguns autores preferem outras denominações. Combe (2009/2010, p. 117), por exemplo, denomina "sujeito lírico" com base, entre outros pontos, na discussão filosófica sobre o sujeito: "Eis assim o quanto a noção de 'eu lírico' parece vinculada à crise filosófica que atravessa o sujeito após o Romantismo, e que Nietzche, ao criticar Descartes, levará ao extremo, denunciando a ilusão gramatical de um 'eu' e da consciência de si no Cogito.". De modo semelhante, Reis prefere chamar de "sujeito poético", tendo, entre seus argumentos, o de que o lirismo nem sempre está no "eu" gramatical, isto é, na primeira pessoa (REIS, 2013, p. 229). As discussões sobre o texto lírico prosseguem, sobretudo quanto às mudanças de uma época a outra, com o uso do verso livre, dos recursos gráficos (poesia concreta) e até mesmo em uma não preocupação com sua característica original de musicalidade - da "lira" de que vem o termo. Em face disso, segue-se, aqui, com o uso consagrado de "eu lírico" para denominar a voz enunciadora interna no poema, levando-se em consideração as questões identitárias, o "eu" como sujeito descentrado (cf. HALL, 2000).

${ }^{3} \mathrm{O}$ uso do termo "coincidência", com o sentido de dupla incidência das vozes internas e externas ao texto, é emprestado de Bakhtin (2011, p. 154, grifo do autor) em sua abordagem da relação entre autor e personagem, quando ele pergunta e responde: "o que torna o autor e sua posição axiológica criadora investida de tanta autoridade na lírica que possibilita a auto-objetivação lírica (a coincidência pessoal da personagem com o autor fora do âmbito de uma obra)? (Pode parecer que na lírica não existem duas
} 
absoluta da relação entre autoria e texto, indo na contramão de boa parte da teoria literária ao longo do século XX, procuram-se levantar algumas das características da produção poética de Mia Couto, contribuindo com os outros elementos que participam do processo de significação.

\section{Autobiografia (não) autorizada}

O tom lírico nos poemas de Mia Couto, isto é, a marcada subjetividade, como se observa, incide em características que se refletem, mais ou menos diretamente, entre os "eus" internos e externos aos textos, entre as diversas características identitárias. Para se rastrear essa relação de implicação das vozes, pode-se iniciar com o poema "Autobiografia", que abre o livro Vagas e lumes (2015), haja vista o que o título propõe, conforme as estrofes a seguir:

Onde eu nasci

há mais terra que céu.

Tanto leito é uma benção

para mortos e sonhadores.

E de tão pouco ser o céu

nasce o Sol

em gretas nos nossos pés

e os corações se apertam

quando remoinhos de poeira

se elevam nos telhados.

$[\ldots]$

Pois,

nessa terra

que é tanta para tão pouco céu,

calhou-me a mim ser ave.

Pequenas que são,

as minhas asas parecem-me enormes.

Envergonhado,

escondo-as dos olhares vizinhos.

Nas minhas costas,

pesam

versos e plumas.

Voarei,

um dia,

sem saber

se é de terra ou de céu

a pegada do voo que sonhei. (COUTO, 2015, p. 11-13)

unidades mas tão somente uma; os círculos do autor e da personagem se fundiram e seus centros coincidiram.)". 
Nesse poema, há um conjunto de motivos espaciais e/ou metáforas que se encontram em outros textos de Mia Couto, como terra, céu, Sol, poeira, aves. Subentendese que, aproximando as vozes, o eu lírico caracteriza Moçambique - nome não citado -, utilizando a metáfora de terra e céu com a diferença de extensão, havendo uma valorização ambivalente, isto é, positiva ("Tanto leito é uma benção") e negativa ("tão pouco céu"). Tal ambivalência se deve ao país ser grande e possuir belezas naturais e culturais, mas ao mesmo tempo ser devastado por guerras e pela fome, o que reduziria o céu, isto é, a possibilidade de uma situação mais positiva aos seus habitantes.

Pode-se considerar, nesse sentido, que o sujeito enunciador se apresenta como moçambicano ("Onde eu nasci"), característica identitária comum ao eu lírico e ao autor "real". Nessa "co-incidência" das vozes (interna e externa ao texto), numa forma de "autoobjetivação lírica" (cf. BAKHTIN, 2011, p. 154) ${ }^{4}$, é assumida, também, a identidade de poeta que, diante daquele espaço moçambicano ambivalente, considera-se "ave". São assumidas, assim, a responsabilidade de escrever ("Nas minhas costas/pesam/versos e plumas"), a humildade ("Pequenas que são"), a função social ("As minhas asas parecemme enormes"), o julgamento ("Envergonhado/escondo-me dos olhares vizinhos"). Ao fim, deixa em dúvida se suas obras cumprirão o que propõem, sobretudo pela relação (pegada) entre texto (voo, sonho) e contexto (terra, céu). Mesmo com todos esses aspectos coincidentes e comprováveis pelo título, o texto literário sempre manterá sua (relativa) autonomia, como explica Aguiar e Silva (1984, p. 223, grifos do autor):

O emissor oculta ou explicitamente presente e actuante no texto literário é uma entidade ficcional, uma construção imaginária, que mantém com o autor empírico e histórico relações complexas e multívocas, que podem ir do tipo marcadamente isomórfico ao tipo marcadamente heteromórfico. Em qualquer caso, porém, nunca estas relações se poderão definir como uma relação de identidade, nem como uma relação de exclusão mútua duas soluções antagonicamente extremas que defluem respectivamente de uma concepção biográfico-confessionalista e de uma concepção rigidamente formalista do texto literário - devendo antes definir-se como uma relação de implicação.

Entre os outros poemas que mais diretamente apresentam os aspectos autobiográficos - ou essa relação de implicação -, estão os dedicados a familiares. $\mathrm{O}$ poema "O habitante" é dedicado ao pai, jornalista e escritor Fernando Couto, morto em 2013, conforme algumas de suas estrofes a seguir:

\section{$[\ldots]$}

No silêncio distraído

de uma varanda

que foi teu único castelo, ecoam ainda os teus passos

feitos não para caminhar

mas para acariciar o chão.

\footnotetext{
${ }^{4} \mathrm{Na}$ contramão da subjetividade pura e simples atribuída à lírica, Bakhtin (2011, p. 139) defende que há uma forma de objetivação do "eu": na autobiografia "posso objetivar artisticamente a mim mesmo e minha vida". Ele ressalta que o texto, nesse caso, interessa mais pelos valores de elaboração artística do que para fins puramente históricos, científicos e/ou práticos (BAKHTIN, 2011, p. 139), isto é, mesmo autobiográfico, o texto é uma construção discursiva artística.
} 
Nessa varanda te sentas

nesse tão delicado modo de morrer

como se nos estivesses ensinando

um outro modo de viver.

Se o passo é tão celeste

a viagem não conta

senão pelo poema que nos veste.

Os lugares que buscaste

não têm geografia.

São vozes, são fontes,

rios sem vontade de mar,

tempo que escapa da eternidade.

Moras dentro,

sem deus nem adeus. (COUTO, 2015, p. 14-15)

Nesse poema, a ausência do pai - não mencionado no texto, a não ser na dedicatória - torna-se presença pelos componentes do espaço, os textos de Mia Couto tendem à espacialidade da experiência humana, como nesse caso da morte de um ente familiar. Como em outros poemas, há menção à "geografia", em sua recusa, talvez porque há sociedades e culturas na África, com suas "vozes" e "fontes", que não se restringem às divisões territoriais feitas pelo colonialismo. Além disso, apesar de serem reconhecidos em Moçambique por suas contribuições ao país, pai e filho defrontam-se com as origens portuguesas da família. Com o poema dedicado ao pai, portanto, o "eu" do texto remete ao autor empírico, de modo que o texto lírico constitui-se, segundo Combe (2009-2010, p. 128), por uma "dupla referência" ou "referência desdobrada", conforme o autor explica tomando por base a alegoria:

$\mathrm{Na}$ alegoria, com efeito, e de modo mais geral em toda figura de elocutio, a significação literal jamais desaparece por trás da significação figurada, mas coexiste com ela: na alegoria medieval, os diferentes níveis de sentido [...] autorizam leituras múltiplas, de tal forma que a consciência - do ouvinte, do leitor do poema lírico - vá de um lado a outro, num movimento contínuo de vaivém. No plano fenomenológico, essa dupla referência parece corresponder a uma dupla intencionalidade por parte do sujeito, ao mesmo tempo voltado para si mesmo e para o mundo, tensionado ao mesmo tempo em direção ao singular e ao universal, de modo que a relação entre a referencialidade autobiográfica e a ficção passa por essa dupla intencionalidade.

Nesse sentido, mais do que expressão da "verdade", quando o autor declara que se trata de autobiografia, e em contraposição à visão romântica de que no lirismo se tem a projeção imediata de emoções do autor empírico, o texto é sempre uma elaboração, artifício, uma "projeção discursiva" sobre si mesmo (REIS, 2013, p. 229). Na autobiografia, como afirma Bakhtin, o autor "deve tornar-se outro em relação a si mesmo, olhar para si mesmo com os olhos do outro" (BAKHTIN, 2011, p. 13, grifos do autor), uma vez que "o indivíduo não existe fora da alteridade" (BAKHTIN, 2011, p. 157-158, grifos do autor). Ainda, segundo Combe (2009-2010, p. 128), o "sujeito lírico se cria no e pelo poema"; por isso, mesmo que ele tenha a intenção de se autorretratar, é preferível 
considerar o texto como uma "dupla referência" - ou coincidência - das vozes do eu interno e do autor empírico.

E, assim como ao pai, há poemas dedicados à esposa, do mesmo modo metafórico, como os "Versos para a Patrícia" no livro Raiz de orvalho (2014, p. 93-94), e "Noite escandinava", publicado no livro Tradutor de chuvas (2011, p. 72-73), em que declara a "saudade da Patrícia". Deste último, composto de onze estrofes, seguem algumas - do início e do final:

Não é a luz que acendo.

Acabei, sim, de acender a noite.

Num instante,

o tecto se torna céu

e o escuro se torna leito.

A noite é escassa

para tanta saudade.

$[\ldots]$

Esta claridade de meia-noite,

este poente que nunca encontra sol,

foram feitos para te roubar da distância.

Nenhuma geografia me vence:

neste matinal crepúsculo

eu te desenho, luar de sombra.

E já não é nem pecado nem sonho:

és tu que acendo

num quase ocaso de Estocolmo. (COUTO, 2011, p. 72-73)

O eu lírico, no que se propõe coincidente com o autor, posiciona-se distante da esposa. As características de Estocolmo, com o verão de dias longos e noites curtas, funcionam como recursos figurativos para a expressão da declarada saudade. Configurase uma espécie de jogo antitético de luz e sombra: "acender a noite", "claridade da meianoite", poente sem sol, "matinal crepúsculo". Ao final, a luz é relacionada à esposa ("és tu que acendo"). Há, novamente, menção à geografia, no caso pela distância da mulher. Como vem sendo destacado, prevalece a espacialidade da experiência humana, isto é, a subjetividade, que se considera como própria da lírica, projeta-se e configura-se pelo espaço. $^{5}$

Em outro texto do livro Raiz de orvalho, há uma carta dedicada ao filho, com data de julho de 1981, em que declara seu amor pelo menino: "[...] te amo de todas as maneiras que sei amar" (COUTO, 2014, p. 95). No livro Vagas e lumes, o poema "Irmão infinito" (2015, p. 84) é dedicado a Carlos Cardoso, jornalista assassinado em 2000. Desse modo, entre os textos com referências mais diretas à realidade, há alguns dedicados a poetas brasileiros. No poema intitulado "Manoel de Barros", o eu lírico, entendido como

\footnotetext{
${ }^{5}$ Para Reis (2013, p. 224), é próprio do texto lírico o "processo de interiorização - do exterior da vida, para o interior - do sujeito poético".
} 
coincidente com o autor, relaciona seu fazer poético com o do poeta brasileiro, como segue:

Dizem que, entre nós,

há oceanos de distância.

Talvez.

Quem sabe de certezas

não é o poeta.

O mundo que é nosso

é sempre tão pequeno e tão infindo

que só cabe em olhar de menino.

Contra essa distância

tu me deste uma sabedora geo-agrafia

e, bebendo a palavra africana,

tornei-me tão vizinho

que ganhei intimidades

com o teu chão brasileiro.

E será sempre

o mesmo catar de verso

entre poeira e grão,

o mesmo peneirar de água,

apartando gotas e silêncios.

E será sempre

a mesma infância nos restituindo a palavra,

a mesma palavra devolvendo a infância.

E assim,

sem lonjura,

na mesma água

riscaremos a palavra

que incendeia a nuvem. (COUTO, 2015, p. 52-53)

Nota-se a identificação com Manoel de Barros, destacando-se uma maneira semelhante de entender a poesia: como infância, com a singularização de coisas simples ou aparentemente "sem valor" (poeira, grão, gotas), além da preferência pelos versos livres. ${ }^{6}$ Em outra menção à "geografia", há uma rasura em favor das "coisas", de se trazer ao poema os elementos e valores culturais "não escritos" ("agrafia"), provavelmente como uma forma de restabelecer ou reequilibrar a relação entre as palavras e as coisas. Tem-se, desse modo, um processo de produção poética que ultrapassa as fronteiras nacionais e continentais, unindo brasileiros e moçambicanos. Assim, a voz enunciadora no poema reúne eu lírico e autor como um "eu poeta" que declara ter, entre suas referências, a poesia de Manoel de Barros.

\footnotetext{
${ }^{6}$ Apesar de se ter a musicalidade na origem da poesia lírica, o que dependeria, em grande parte, da rima, houve mudanças e transformações, como a instituição do verso livre, o que teria acentuado "a libertação do ritmo", adequando "à fluidez dos sentidos representados" (REIS, 2013, p. 237).
} 
Outros poemas em que os aspectos autobiográficos podem ser mais facilmente reconhecidos envolvem o grupo de moçambicanos que lutou contra o colonialismo, uma voz coletiva em primeira pessoa ("nós") em oposição aos colonizadores, como nos seguintes trechos do início e do final do poema "Eles", de 1979 (in Raiz de orvalho, 2014, p. 32):

Desde que chegaram

ficou sem repouso a baioneta

e os chicotes tornaram-se

atentos e sem desleixo

Lançaram fogo

à dolorida geografia

esquartejaram montanhas

secaram fontes e rios

na memória dos seus crimes

se anichou a seta da vingança

$[\ldots]$

Colocámos o sonho no arco

e dele fizemos flecha certeira

e transportámo-nos no vento

como se fôssemos a semente derradeira

Para sermos homens

desocupamos o silêncio

e com um firmamento de esperança

cobrimos o rosto ferido da nossa Pátria (COUTO, 2014, p. 32-34)

Para a compreensão desse poema, ou para uma leitura mais ampla, é necessário recorrer ao contexto histórico de Moçambique, país que assim se fez, tornou-se independente de Portugal, em 1975. Têm-se "eles" (colonizadores portugueses) e "nós" (moçambicanos colonizados). Nascido em Moçambique, mas descendente de portugueses, Mia Couto fez parte da FRELIMO (Frente de Libertação de Moçambique), posicionando-se sempre do lado do "nós", daqueles que lutavam pela independência. A relação de implicação entre as vozes do texto requer que se considerem as informações externas, como explica Aguiar e Silva (1984, p. 223):

O teor dessa relação, principalmente sob os pontos de vista psicanalítico, sociológico e ideológico, assume grande relevância em todo o processo da comunicação literária e só pode ser determinado e caracterizado com fundamento na análise do próprio texto literário, articulando-a com o estudo de outras fontes de informação exteriores ao texto e atinentes ao autor empírico e histórico, ao seu processo de produção literária, em geral, e ao processo de produção do texto em causa, em particular. 
Da mesma forma que o poema "Eles", é com base em dados históricos de Moçambique que se pode depreender, de modo mais completo, os sentidos do poema "Companheiros", de 1984 (2014, p. 83-84), como segue:

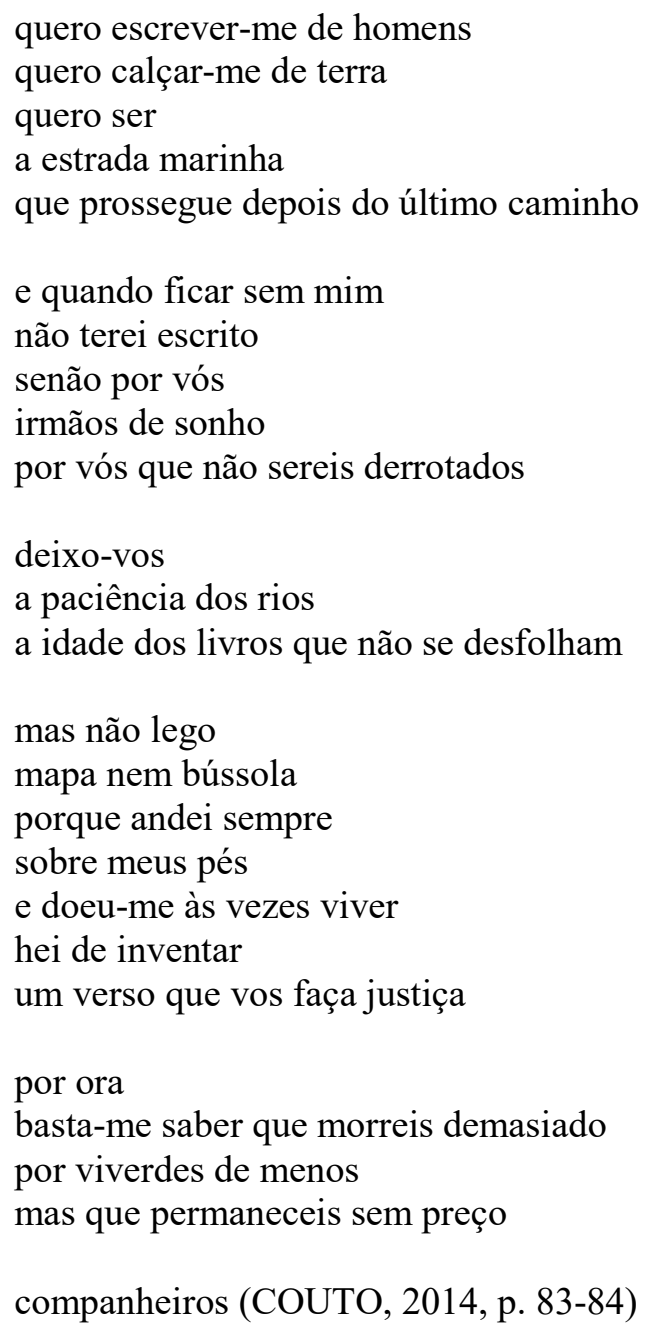

Nesse poema, o eu lírico apresenta-se novamente como "eu poeta" e, na coincidência com o autor, dirige-se aos companheiros, assumindo que sua luta se fará pela literatura. Após a independência do país, houve uma guerra pelo poder, quando outro grupo, a RENAMO (Resistência Nacional Moçambicana), não aceitou que a FRELIMO governasse o país. Pode-se entender, pela aproximação das vozes implicadas no texto, que os "companheiros" são alguns dos membros da FRELIMO. No poema "Identidade", de 1977, o eu lírico mostra-se também engajado:

Preciso ser um outro

para ser eu mesmo

Sou grão de rocha

Sou o vento que a desgasta

Sou pólen sem inseto 
Sou areia sustentando

o sexo das árvores

Existo onde me desconheço

aguardando pelo meu passado

ansiando a esperança do futuro

No mundo que combato

morro

no mundo por que luto

nasço (COUTO, 2014, p. 13)

A voz enunciadora aproxima-se do autor naquela época - embora de modo mais implícito do que nos poemas analisados anteriormente -, quando se conquistava a independência e havia esperança pelo futuro do país que se projetava. Porém, com a guerra que se seguiu e com os outros obstáculos do poder, a nação sonhada estava longe de se concretizar. Anos depois, Mia Couto deixou a FRELIMO e em seu primeiro romance publicado, Terra sonâmbula (1992), denunciou a corrupção de administradores do governo. Trata-se do momento, segundo Cabaço (2004, p. 69), em que "a identidade do escritor desce do projeto da Utopia para o patamar do possível". Mesmo assim, suas obras seguiram com o contraponto entre o "sonho" (esperança) de se construir uma nação com menos problemas sociais e a crítica à situação política. Nesse sentido, há o "Poema didáctico":

Já tive um país pequeno,

tão pequeno

que andava descalço dentro de mim.

Um país tão magro

que no seu firmamento

não cabia senão uma estrela menina,

tão tímida e delicada

que só por dentro brilhava.

Eu tive um país

escrito sem maiúscula.

Não tinha fundos

para pagar a um herói.

Não tinha panos

para costurar bandeira.

Nem solenidade

para entoar um hino.

Mas tinha pão e esperança

para os viventes

e sonhos para os nascentes.

Eu tive um país pequeno,

tão pequeno

que não cabia no mundo. (COUTO, 2011, p. 52-53) 
Embora não se especifique de que país exatamente se trata, coincide com Moçambique, onde a miséria e a fome atingem grande parte da população. Como em um sonho ou projeção ao futuro, havia "pão e esperança", uma solução simples que não se realizava ("não cabia no mundo"). Para a construção da nação, em vez do alimento ser prioridade, a preocupação do governo estava na bandeira, nos heróis e no hino. A FRELIMO, então, como explica Borges Coelho (2009, p. 65), perdia "o monopólio da versão da história inscrita na sua modernidade", deixando de haver uma só versão... passaram a competir várias, contraditórias". Dessa maneira, afastando-se da política, ao menos diretamente, Mia Couto continua preocupado com a nação, mas assumindo a função de escritor. No poema "Meus julhos", de 1989, incluído em nova edição de Raiz de orvalho (2014), a voz enunciadora declara sua opção pela poesia:

\author{
1. Sou julho \\ estou explicado só pelo sol \\ Meu erro \\ é procurar um território \\ apto a nascer \\ A única geografia \\ que me aceita é a poesia \\ [...] (COUTO, 2014, p. 69)
}

Nascido em julho, Mia Couto tem a sua voz coincidida com a do eu lírico, em que se tem, novamente, o "eu" poeta e moçambicano, ratificando o vínculo com o lugar: sol de julho em Moçambique, a poesia como "geo-grafia" (escrita da terra). Em outros poemas, a dupla incidência das vozes até pode ser considerada, mas de modo mais implícito, sem delimitar a interpretação. Um desses casos é o "Poema mestiço":

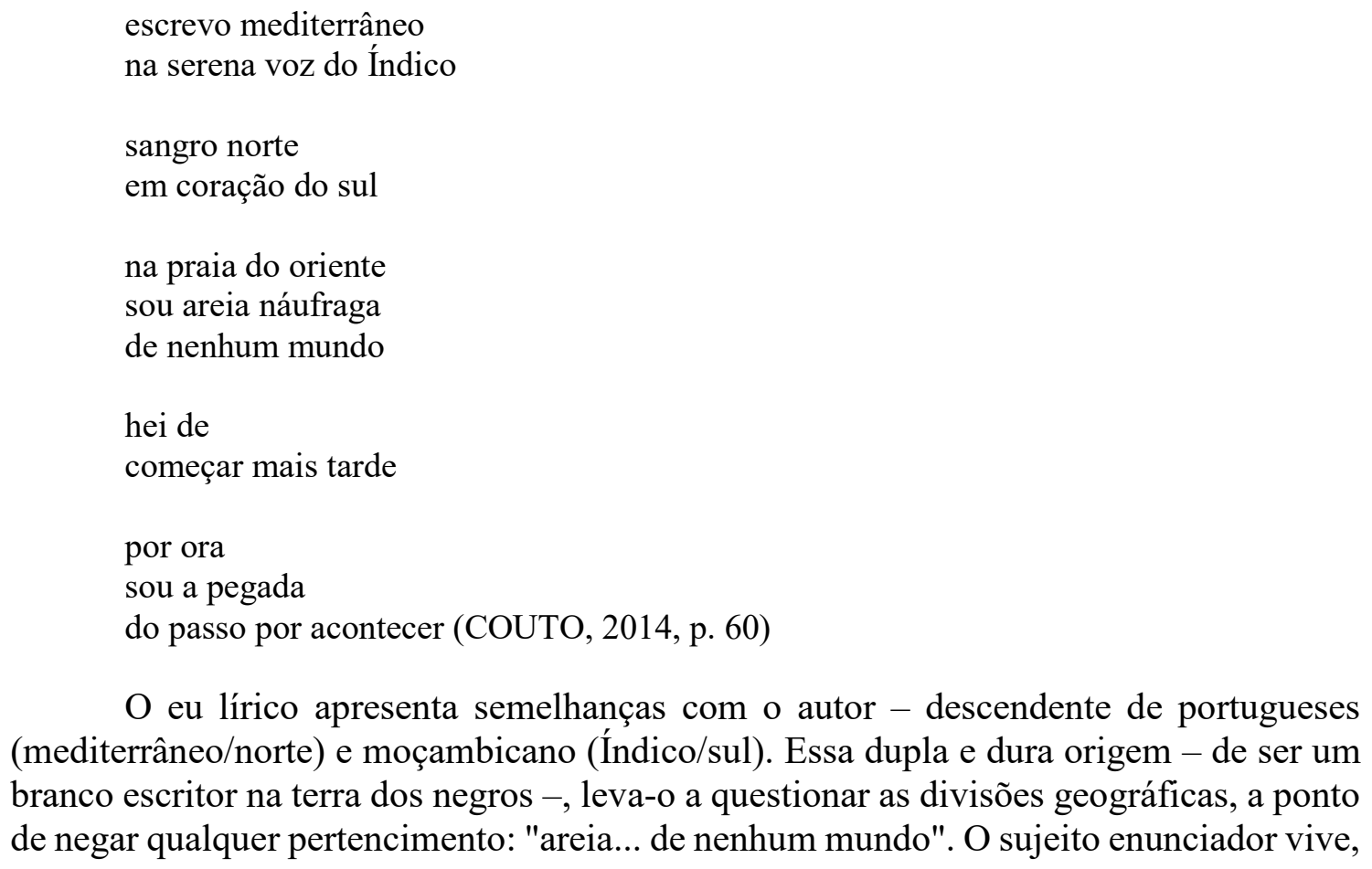

O eu lírico apresenta semelhanças com o autor - descendente de portugueses (mediterrâneo/norte) e moçambicano (Índico/sul). Essa dupla e dura origem - de ser um branco escritor na terra dos negros -, leva-o a questionar as divisões geográficas, a ponto de negar qualquer pertencimento: "areia... de nenhum mundo". O sujeito enunciador vive, 
então, entre culturas e histórias do passado (pegada) e o futuro (por acontecer). De modo implícito, também, podem ser notadas coincidências das vozes no poema "Sotaque da terra", especialmente nos versos: "porque falo/a língua do chão" e "minha voz/ficou cativa do mundo/pegadas nas areias do Índico" (COUTO, 2014, p. 65). Como o eu lírico nesse poema, Couto procura ser um escritor que trata de sua terra, tendo como principais referências as tradições dos povos que formam Moçambique. E, após desistir do curso de medicina $^{7}$, ele assume-se poeta como a voz enunciadora no poema "Deslição de anatomia":

Quase fui médico

Cedo acreditei

ter inclinação.

Aconteceu, em menino,

frente aos compêndios escolares.

Fascinava-me,

no humano corpo,

o vocabulário em flor:

o suco gástrico,

o bolo alimentar,

o trânsito intestinal,

as papilas gustativas.

Ante o meu prematuro pasmo,

a professora vaticinou: vai ser médico!

Em casa, porém,

meu pai diagnosticou diverso:

não era anatomia que me atraía.

Eu apenas amava as palavras.

Meu pai adivinhava.

E eu, de poesia, adoecia. (COUTO, 2011, p. 41)

Nessas coincidências entre o que apresenta a voz interna do poema e os dados biográficos de Mia Couto, a poesia é tida metaforicamente, no jogo de significado com a medicina, como uma doença, como algo que não se pode evitar. E, se o poema fala de "deslição", remetendo aos "deslimites da palavra" de Manoel de Barros (1993), vale lembrar a "lição" de Fernando Pessoa, em seu poema "Autopsicografia", quanto ao poeta ser "um fingidor" (1995). ${ }^{8}$ Logo, ao mesmo tempo em que há semelhanças entre a vida

\footnotetext{
${ }^{7}$ Anos depois, após trabalhar como jornalista, Mia Couto formou-se em Biologia, área em que também atua.

${ }^{8}$ É bastante comum recorrer-se ao poema de Pessoa para defender a diferença ou o distanciamento entre o eu lírico e o autor empírico (poeta), o que evita restringir os sentidos dos poemas à biografia do escritor. Esse poema possui muitas interpretações, havendo controvérsias, porém grande parte de seus estudiosos consideram que ele está mais próximo da perspectiva da autonomia do texto: "Foi exatamente para afirmar o carácter modelado do sujeito poético que Fernando Pessoa concebeu e enunciou uma teoria poética assente no princípio do fingimento", opondo-se ao pressuposto romântico de que texto é sempre uma "projeção imediata de emoções e experiências efetivamente sentidas pelo autor empírico" (REIS, 2013, p. 228-229). Pode-se entender que Pessoa não exclui a relação de implicação pelo que afirma nos dois
} 
de Mia Couto com a do eu lírico do poema, pode haver, também, em parte, uma "ficcionalização".

\section{Questão da autoria e os vários "eus" - considerações finais}

O conceito de autoria, após passar de um extremo a outro, do período romântico que supervaloriza a biografia até meados do século XX, quando Barthes declara a "morte do autor" (2004), precisa ser repensado, tendo em vista reencontrar o equilíbrio entre essas posições. Como se observa nos poemas de Mia Couto, deve-se evitar a generalização, visto que há poemas em que se reconhece um tom pessoal, individual, próximo ou coincidente com o autor empírico, e outros, não analisados aqui, em que o eu lírico não parece coincidir. Há estudiosos que têm contribuído para a revisão da função do autor, mas a questão continua complexa, como explica Reis (2013, p. 39-40):

A autoria literária tende, pois, a desvincular-se da pessoa palpável do escritor, que, por assim dizer, perde legitimidade para condicionar ou orientar a leitura da sua obra; essa é, de resto, uma questão não isenta de algum melindre, uma vez que não é raro que o escritor tente interferir na fortuna literária da sua obra, por várias formas: propondo interpretações, tentando corrigir leituras, retirando do mercado obras suas, reescrevendoas de forma mais ou menos extensiva e mesmo (de forma eticamente criticável) estimulando por várias formas a valorização crítica e institucional dos seus livros.

Apesar de haver diferenças entre as vozes internas e externas do texto, entre o autor textual e o empírico, não deixa de haver relações de implicação. Pode-se questionar, desse modo, a separação absoluta entre autoria e texto, visto que, muitas vezes, dados externos podem contribuir para a interpretação. Buscando uma via intermediária entre a intenção do autor e a autonomia do texto, Compagnon critica as teses intencionalistas deterministas (românticas) e as anti-intencionalistas, em especial a da "falácia intencional" de Wimsatt e Beardsley (2002), afirmando que, quando "alguém escreve um texto, tem certamente a intenção de exprimir alguma coisa, quer dizer alguma coisa", mesmo que, após publicá-lo, o autor não detenha o controle do sentido (COMPAGNON, 1999, p. 80). Para o teórico, interpretar um texto é "sempre fazer conjeturas sobre uma intenção humana" (Ibidem, p. 49) e que "se o outro não pode ser integralmente desvendado, pode, ao menos, ser um pouco compreendido" (Ibidem, p. 80).

Nos poemas e nas crônicas, diferentemente dos contos e romances, Mia Couto tende mais ao tom pessoal, a deixar que, mesmo implicitamente, apareçam semelhanças entre o eu lírico e suas características biográficas. Na poesia lírica, como afirma Reis (2013, p. 228), o autor empírico pode "projetar sinuosamente no mundo do texto experiências realmente vividas", assim como "a voz que nesse texto nos fala pode ignorar... subverter, metaforizar... essas experiências". Pode haver, portanto, um fingimento ou a "ficcionalização" de sua biografia, até mesmo o autor que assina os textos, "Mia Couto", pode ser "ficcionalizado" e não totalmente coincidente com António Emílio Leite Couto - seu nome verdadeiro completo. Como ele próprio afirmou a respeito do uso da língua portuguesa em Moçambique e na literatura, o escritor "não se serve da língua, o criador literário é inventado" por ela (COUTO, 2012, p. 173).

últimos versos da primeira estrofe: O poeta "...chega a fingir que é dor/ a dor que deveras sente" (PESSOA, 1995, p. 44). 
Em sua análise da questão da autoria, Foucault (1969, p. 43-44) diferencia o "nome próprio" do "nome do autor", afirmando que "têm seguramente alguma ligação", mas que "não funcionam da mesma maneira", estando o segundo, para a crítica literária moderna, relacionado a uma busca de unidade dos textos:

O autor é aquilo que permite explicar tanto a presença de certos acontecimentos numa obra como as suas transformações, as suas deformações, as suas modificações diversas (e isto através da biografia do autor, da delimitação da sua perspectiva individual, da análise da sua origem social ou da sua posição de classe, da revelação de seu projeto fundamental). $\mathrm{O}$ autor é igualmente o princípio de uma certa unidade de escrita, [...]. $\mathrm{O}$ autor é ainda aquilo que permite ultrapassar as contradições que podem manifestar-se numa série de textos [...], um ponto a partir do qual as contradições se resolvem, os elementos incompatíveis se encaixam uns nos outros ou se organizam em torno de uma contradição fundamental ou originária. [...] Mas a função autor não é, com efeito, uma pura e simples reconstrução que se faz em segunda mão a partir do texto tido com um material inerte. $\mathrm{O}$ texto traz sempre consigo um certo número de signos que reenviam para um autor. (FOUCAULT, 1969, p. 53-54)

A relevância da autoria, portanto, decorre de uma necessidade de se "enxergar" um texto - ler e criticá-lo - em relação aos demais textos, a grupos de textos, buscando uma unidade em meio à diversidade ou em meio às contradições. ${ }^{9}$ A função do autor no discurso romanesco em primeira pessoa, como explica Foucault, não coincidindo necessariamente com o escritor ou com a pessoa real (de "nome próprio"), reenvia os signos "para um 'alter-ego' cuja distância relativamente ao escritor pode ser maior ou menor e variar ao longo da própria obra" (FOUCAULT, 1969, p. 56). É nesse sentido que se tem uma maior ou menor proximidade entre o eu lírico, o autor textual e a "pessoa real" (marido de Patrícia, por exemplo) nos poemas de Mia Couto, entrecruzando-se várias identidades. A esse respeito, conclui Foucault (1969, p. 56-57):

Todos os discursos que são providos da função autor comportam esta pluralidade de "eus". [...] A função autor está ligada ao sistema jurídico e institucional que encerra, determina, articula o universo dos discursos; não se exerce uniformemente e da mesma maneira sobre todos os discursos, em todas as épocas e em todas as formas de civilização; não se define pela atribuição espontânea de um discurso ao seu produtor, mas através de uma série de operações específicas e complexas; não reenvia pura e simplesmente para um indivíduo real, podendo dar lugar a vários "eus" em simultâneo, a várias posiçõessujeitos...

Essas posições não são sempre ocupadas pacificamente, no contexto moçambicano, como ressalta Noa (2009, p. 96), mas com tensões "porque se trata de identidades problemáticas, dado que resultam quase sempre de hibridismos culturais, linguísticos, raciais... surgem inevitavelmente como dimensões difusas, oscilantes e perturbadoras". Como afirma Cabaço (2004, p. 69), o "escritor, uma vez confrontado com o problema da identidade, nunca mais dele se vai livrar", é "seu destino e essa é a riqueza

\footnotetext{
${ }^{9}$ Para Bourdieu (1998, p. 186) - em seu questionamento da biografia como relato de uma história linear, coerente e totalizante, em prol de um entendimento do real como descontínuo, formado por elementos justapostos sem razão, surgidos de modo imprevisto, aleatório e nem sempre coerente - o "nome próprio" também tende a reunir várias identidades, a funcionar como um ponto de estabilidade em um mundo instável, assegurando "a constância através do tempo e a unidade através dos espaços sociais dos diferentes agentes sociais que são a manifestação dessa individualidade nos diferentes campos".
} 
da literatura". Assim, no limite entre autobiografia autorizada e não autorizada, visto que os poemas seguem abertos à interpretação, notam-se as várias identidades cruzando-se em torno do "eu" nos poemas de Mia Couto: poeta, moçambicano, membro da FRELIMO, esposo, filho, pai, descendente de portugueses e, talvez, em outros textos, possam ser encontradas muitas outras ainda.

\section{REFERÊNCIAS}

AGUIAR E SILVA, V. M. de. Teoria da literatura. 6. ed. Coimbra: Almedina, 1984.

BAKHTIN, M. M. Estética da Criação Verbal. 6. ed. São Paulo: Martins Fontes, 2011.

BARROS, M. de. Livro das ignorãnças. Rio de Janeiro: Record, 1993.

BARTHES, R. A morte do autor. In: O Rumor da Língua. São Paulo: Martins Fontes, 2004. p. 57-64.

BORGES COELHO, J. P. E depois de Caliban? A história e os caminhos da literatura no Moçambique contemporâneo. In: GALVES, C.; GARMES, H.; RIBEIRO, F. R. (Org.). África-Brasil: Caminhos da língua portuguesa. Campinas: Ed. UNICAMP, 2009. p. $57-$ 68.

BOURDIEU, P. A ilusão biográfica. In: FERREIRA, M. de M.; AMADO, J. Usos e abusos da história oral. Rio de Janeiro: Ed. FGV, 1998. p. 183-191.

CABAÇO, J. L. A questão da diferença na literatura moçambicana. Via Atlântica, São Paulo: USP, n. 7, p. 61-69, 2004.

COMBE, D. A referência desdobrada: o sujeito lírico entre a ficção e a autobiografia. Revista USP, n. 84, p. 112-128, dez./fev. 2009-2010.

COMPAGNON, A. O demônio da teoria: literatura e senso comum. Belo Horizonte: Ed. UFMG, 1999.

COUTO, M. Vagas e lumes. 2. ed. Alfragide: Caminho, 2015.

. Raiz de orvalho e outros poemas. 5. ed. Alfragide: Caminho, 2014.

Letras, 2012 .

Tradutor de chuvas. Alfragide: Caminho, 2011.

Terra sonâmbula. São Paulo: Companhia das Letras, 2007.

FOUCAULT, M. O que é um autor? Lisboa: Passagens, 2002[1969].

HALL, S. A identidade cultural na pós-modernidade. 4. ed. Rio de Janeiro: DP\&A, 2000.

NOA, F. As falas das vozes desocultas: a literatura como restituição. In: GALVES, C.; GARMES, H.; RIBEIRO, F. R. (Org.). África-Brasil: Caminhos da língua portuguesa. Campinas: Ed. UNICAMP, 2009. p. 85-100.

PESSOA, F. Autopsicografia. In: PASSONI, C. A. N. (Org.). As múltiplas faces de Fernando Pessoa. 2. ed. São Paulo: Núcleo, 1995.

REIS, C. O conhecimento da literatura: introdução aos estudos literários. 2. ed. Porto Alegre: Ed. PUC-RS, 2013. 
WIMSATT, W. K.; BEARDSLEY, M. C. A falácia intencional. In: LIMA, L. C. (Org.). Teoria da literatura em suas fontes. v. 2. 3. ed. Rio de Janeiro: Civilização Brasileira, 2002. p. 639-656.

Recebido em: 22/09/2017

Aprovado em: 06/11/2017 